\title{
Assessing the Susceptibilty of Some Gut Bacteria to the Extract from Needles of Turkish Pine
}

\author{
Baそฺ Bağırsak Bakterilerinin Türk Çamı İ̆nnelerinden Elde Edilen Ekstrakta Duyarlhlklarmm Değerlendirilmesi
}

\author{
Ahu DEMİRTAŞ ${ }^{*}$ (iD) \\ ${ }^{1}$ Burdur Mehmet Akif Ersoy University, Faculty of Veterinary Medicine, Department of Physiology, Burdur, Turkey
}

\begin{abstract}
Plant extracts have the potential to be safe alternatives to antibiotics that disrupt the gut flora. The aim of the present study was to assess the susceptibility of some gut bacteria to the extract from needles of Turkish pine (Pinus brutia Ten.) using microdilution method in an anaerobic chamber. Turkish pine needle extract promoted the growth of Bifidobacterium bifidum, Bifidobacterium infantis, and Lactobacillus acidophilus from gut commensals at 0.2-6.25 $\mathrm{mg} / \mathrm{mL}, 0.4-6.25 \mathrm{mg} / \mathrm{mL}$, and $0.4-1.6 \mathrm{mg} / \mathrm{mL}$ dose ranges, respectively $(P<0.05)$. However, the extract had a potential inhibitory activity on Bifidobacterium species starting from $12.5 \mathrm{mg} / \mathrm{mL}$, on L. acidophilus starting from 6.25 $\mathrm{mg} / \mathrm{mL}$, and on $L$. casei starting from $3.13 \mathrm{mg} / \mathrm{mL}$ concentrations $(P<0.05)$. Minimal inhibitory concentration (MIC) was $25 \mathrm{mg} / \mathrm{mL}$ for all commensal species $(P<0.05)$. Turkish pine needle extract also showed a potential inhibitory activity against gut pathogens Eschericbia coli and Clostridium perfringens from $0.4 \mathrm{mg} / \mathrm{mL}$ dose and against Staphylococcus aureus and Fusobacterium nucleatum from $0.8 \mathrm{mg} / \mathrm{mL}$ dose $(P<0.05)$. The MICs were $6.25,12.5,25$, and $50 \mathrm{mg} / \mathrm{mL}$ for $S$. aureus, F. nucleatum, E. coli, and C. perfringens, respectively $(P<0.05)$. It was concluded that using the Turkish pine needle extract in a dose range of $0.2-6.25 \mathrm{mg} / \mathrm{mL}$, where it protected most of the commensal bacteria and was toxic against some of the pathogens, might produce desirable impacts in the gut.
\end{abstract}

Keywords: Antibacterial, Gut bacteria, MIC, Plant extracts, Turkish pine needle.

Öz: Bitki ekstraktları, bağırsak florasını bozan antibiyotiklere güvenli alternatifler olma potansiyeline sahiptir. Bu çalışmanın amacı, anaerobik bir kabinde mikrodilüsyon yöntemi kullanılarak bazı bağırsak bakterilerinin Türk çamı (Pinus brutia Ten.) iğnelerinden elde edilen ekstrakta duyarlllığını değerlendirmektir. Türk çamı iğnesi ekstraktı, bağırsak yerleşik bakterilerinden Bifidobacterium bifidum, Bifidobacterium infantis ve Lactobacillus acidophilus'un büyümesini sırasıyla $0,2-6,25 \mathrm{mg} / \mathrm{mL}, 0,4-6,25 \mathrm{mg} / \mathrm{mL}$ ve $0,4-1,6 \mathrm{mg} / \mathrm{mL}$ doz aralıklarında uyarmıştır $(P<0,05)$. Bununla birlikte, ekstrakt, Bifidobacterium türleri üzerine $12,5 \mathrm{mg} / \mathrm{mL}, L$. acidophilus üzerine $6,25 \mathrm{mg} / \mathrm{mL}$ ve $L$. casei üzerine ise $3,13 \mathrm{mg} / \mathrm{mL}$ konsantrasyonlardan başlayarak potansiyel bir inhibitör aktivite göstermiştir $(P<0,05)$. Minimal inhibitör konsantrasyonun (MİK), tüm yerleşik türler için $25 \mathrm{mg} / \mathrm{mL}$ olduğu gözlenmiştir $(P<0,05)$. Türk çamı iğnesi ekstraktı ayrıca bağırsak patojenleri olan Escherichia coli ile Clostridium perfringens'e karşı $0,4 \mathrm{mg} / \mathrm{mL}$ dozdan ve Staphylococcus aureus ile Fusobacterium nucleatum'a karşı ise $0,8 \mathrm{mg} / \mathrm{mL}$ dozdan başlayarak potansiyel bir inhibitör aktivite göstermiștir $(P<0,05)$. Staphylococcus aureus, F. nucleatum, E. coli ve $C$. perfringens için MïK değerlerinin sırasıyla $6,25,12,5,25$ ve $50 \mathrm{mg} / \mathrm{mL}$ olduğu gözlenmiştir $(P<0,05)$. Türk çam iğnesi ekstraktının, yerleşik bakterilerin çoğunu koruduğu ve bazı patojenlere karşı toksik olduğu $0,2-6,25 \mathrm{mg} / \mathrm{mL}$ doz aralı̆̆ında kullanılmasının bağırsaklarda arzu edilen etkiler oluşturabileceği sonucuna varılmıştır.

\begin{tabular}{|c|c|}
\hline \multicolumn{2}{|c|}{ Anahtar Kelimeler: Antibakteriyel, Bağırsak bakterileri, Bitki ekstraktları, MİK, Türk çamı iğnesi. } \\
\hline *Corresponding author : Ahu DEMİRTAŞ & e-mail : ahu-demirtas@hotmail.com \\
\hline Geliş & Kabul tarihi / Accepted: 03.03.2021 \\
\hline Introduction & $\begin{array}{l}\text { great importance in terms of maintaining the gut } \\
\text { health. Conventional antibiotics can prevent the }\end{array}$ \\
\hline $\begin{array}{l}\text { The gut flora is a large and dynamic bacterial } \\
\text { community that participates in normal } \\
\text { physiological functions, but also protects against } \\
\text { pathogens by forming a defensive barrier and } \\
\text { competing for available substrates (Ahn et al., }\end{array}$ & $\begin{array}{l}\text { growth of both commensal and pathogenic } \\
\text { species and decrease diversity of the gut flora } \\
\text { (Bäumler and Sperandio, 2016). In recent years, } \\
\text { many studies have been focused on plant extracts }\end{array}$ \\
\hline
\end{tabular}
1998; Canny and McCormick, 2008). Balance between commensal and pathogenic species has 
Turkish pine or Turkish red pine (Pinus brutia Ten.) is the most common pine species in Turkey which has ability to grow on a wide range of Mediterranean- and Black Sea regions (Balaban Ucar et al., 2013). The use of Turkish pine in the forest products industry has been widely accepted because of its suitability for the manufacture of desirable products (Üner et al., 2011). In a previous study, we observed that the extract from barks of Turkish pine, which containing phenolic compounds, had a potential to inhibit pathogenic bacteria in the gut while protect commensal ones (Demirtaş, 2020). Furthermore, Pinus densiflora (Japanese pine) leaf derived components, (1R)$(+)-\alpha$-pinene and limonene, strongly inhibited the growth of Staphylococcus aureus, Escherichia coli, and Clostridium perfringens without adverse effects on the growth of five commensal bacteria (Bifidobacterium bifidum, B. longum, B. adolescentis, Lactobacillus acidopbilus, and L. caser) (Hwang and Lee, 2002). The needle of Turkish pine also contains several flavonoids (Kaundun et al., 1997) and essential oil components (Yener et al., 2014) with antioxidant and antibacterial capacity. However, the effects of extract from Turkish pine needle on gut bacteria have not been evaluated previously. Therefore, the aim of the present study was to assess the susceptibility of some gut bacteria to the extract from needles of Turkish pine.

\section{Materials and Methods}

\section{Turkish pine needle extract}

Turkish pine needle extract was provided by Kale Naturel Herbal Products Company, Ltd., Balikesir, Turkey.

\section{Preparation of bacteria}

Commensal bacterial species used in antibacterial tests were Bifidobacterium bifidum ATCC 29521, Bifidobacterium longum subsp. infantis ATCC 15697, Lactobacillus acidopbilus ATCC 4356, and Lactobacillus casei ATCC 393. Pathogenic bacterial species were Stapbylococcus aureus subsp. aureus ATCC 12600, Escherichia coli ATCC 11775, Clostridium perfringens ATCC 13124, and Fusobacterium nucleatum subsp. nucleatum ATCC 25586. The growth medium was Mann Rogosa
Sharpe (MRS) broth for B. infantis, L. acidophilus, and $L$. case $i$; MRS broth with $0.05 \%$ cysteine (MRS-C) for B. bifidum; tryptic soy broth (TSB) for S. aureus; Luria-Bertani (LB) medium for E. coli and; liquid form of medium 2 (Hobson, 1969) for $C$. perfringens and $F$. nucleatum. Medium 2 was prepared under $\mathrm{CO}_{2}$ as described by Hobson (1969) with only slight modification. Trypticase peptone was used instead of casitone in medium 2 (Table 1). All strains were grown for $24 \mathrm{~h}$ at $37^{\circ} \mathrm{C}$ under an atmosphere of $80 \% \mathrm{~N}_{2}, 10 \% \mathrm{CO}_{2}$, and $10 \% \mathrm{H}_{2}$ in an anaerobic chamber (Don Whitley, Whitley DG250, West Yorkshire, UK).

Table 1. Composition of medium 2 (for $100 \mathrm{~mL}$ )

\begin{tabular}{|c|c|}
\hline \multicolumn{2}{|l|}{ Component } \\
\hline $\begin{array}{l}\text { Trypticase peptone (BD } 211921 \\
\text { Bacto }^{\mathbf{T M}} \text { ) }\end{array}$ & $1.0 \mathrm{~g}$ \\
\hline Yeast extract (Sigma Y1625) & $0.25 \mathrm{~g}$ \\
\hline Mineral solution 1 & $15 \mathrm{~mL}$ \\
\hline Mineral solution 2 & $15 \mathrm{~mL}$ \\
\hline Clarified rumen fluid & $20 \mathrm{~mL}$ \\
\hline Resazurin (Sigma R7017) & $0.0001 \mathrm{~g}$ \\
\hline Sodium lactate $(70 \% \mathrm{w} / \mathrm{v})$ & $1.0 \mathrm{~g}$ \\
\hline Glucose & $0.2 \mathrm{~g}$ \\
\hline Maltose & $0.2 \mathrm{~g}$ \\
\hline Cellobiose (Sigma 22150) & $0.2 \mathrm{~g}$ \\
\hline Cysteine HCl (Sigma C7880) & $0.05 \mathrm{~g}$ \\
\hline $\mathrm{NaHCO}_{3}($ Sigma S5761) & $0.4 \mathrm{~g}$ \\
\hline Deionized water & to $100 \mathrm{~mL}$ \\
\hline $\begin{array}{l}\text { Mineral solution } 1-3 \mathrm{~g} / \mathrm{L} \mathrm{K}_{2} \mathrm{HPO} \\
\text { Mineral solution } 2-3 \mathrm{~g} / \mathrm{L} \mathrm{KH}_{2} \mathrm{PO}_{4} \\
\mathrm{~g} / \mathrm{L}\left(\mathrm{NH}_{4}\right)_{2} \mathrm{SO}_{4}(\text { Sigma A4915), } 6 \mathrm{~g} \\
\mathrm{S} 7653), 0.6 \mathrm{~g} / \mathrm{L} \mathrm{MgSO} \mathrm{M}_{4} \bullet \mathrm{H}_{2} \mathrm{O} \text { (Sign } \\
0.6 \mathrm{~g} / \mathrm{L} \mathrm{CaCl} \mathrm{C}_{2} \text { (Sigma C1016). Clarifi } \\
\text { ruminal fluid brought from the sla } \\
\text { mixed and filtered through three laye } \\
\text { to partition into liquid and solid ( } \\
\text { The liquid fraction was centrifuged at } \\
\text { the clear supernatant was used as a c } \\
\text { anaerobic medium. }\end{array}$ & $\begin{array}{l}\text { 4(Sigma P3786); } \\
\text { (Sigma P9791), } 6 \\
\text { / L NaCl (Sigma } \\
\text { ma 230391), and } \\
\text { ed rumen fluid - } \\
\text { ghterhouse was } \\
\text { rs of cheesecloth } \\
\text { igesta) fractions. } \\
15000 \mathrm{rpm} \text {, and } \\
\text { omponent of the }\end{array}$ \\
\hline
\end{tabular}

\section{Antibacterial screening}

The effect of Turkish pine needle extract on the growth of gut bacteria was tested by a broth dilution method in the anaerobic chamber (CLSI, 2016). A stock solution was prepared by dissolving pine needle extract in 50\% ethanol. Ten serial dilutions of the extract starting at a concentration of $50 \mathrm{mg} / \mathrm{mL}$ were prepared from the stock solution in the bacterial strain specific 
growth media. Two hundred microliters of each dilution were added to wells of a 96-well plate. Next, $20 \mu \mathrm{L}$ of the test bacteria suspension was inoculated into each well. Each bacterium was tested in triplicate wells. Plates were incubated for $24 \mathrm{~h}$ at $37^{\circ} \mathrm{C}$ in the anaerobic chamber. Bacterial growth was detected with a microplate reader at $600 \mathrm{~nm}$ (Epoch, BioTek, USA). The minimal inhibitory concentration (MIC) is defined as the lowest concentration of added extract at which no significant bacterial cell growth was observed. A significantly lower $\mathrm{OD}_{600}$ value compared to control dose $(0 \mathrm{mg} / \mathrm{mL})$ was accepted as potential inhibitory activity (Ko et al., 2018) while significantly higher value was accepted as stimulatory effect (Das et al., 2015).

\section{Statistical analyses}

Statistical analysis was carried out by the use of one-way ANOVA followed by Dunnett's test. Each well of a 96-well plate was an experimental unit. A probability value at $P<0.05$ was considered statistically significant.

\section{Results}

Effects of Turkish pine needle extract on gut bacteria are showed in Figure 1 and Figure 2. Turkish pine needle extract promoted the growth of B. bifidum, B. infantis, and L. acidopbilus from gut commensals at $0.2-6.25 \mathrm{mg} / \mathrm{mL}, \quad 0.4-6.25$ $\mathrm{mg} / \mathrm{mL}$, and $0.4-1.6 \mathrm{mg} / \mathrm{mL}$ dose ranges, respectively $(P<0.05)$. That effect was more obvious for B. infantis. However, the extract had a potential inhibitory activity on Bifidobacterium species starting from $12.5 \mathrm{mg} / \mathrm{mL}$, on $L$. acidophilus starting from $6.25 \mathrm{mg} / \mathrm{mL}$, and on $L$. casei starting from $3.13 \mathrm{mg} / \mathrm{mL}$ concentrations $(P<0.05)$. The MIC was $25 \mathrm{mg} / \mathrm{mL}$ for all commensal species $(P<0.05)$ (Table 2$)$. Turkish pine needle extract also showed a potential inhibitory activity against gut pathogens E. coli and C. perfringens from $0.4 \mathrm{mg} / \mathrm{mL}$ dose and against $S$. aureus and $F$. nucleatum from $0.8 \mathrm{mg} / \mathrm{mL}$ dose $(P<0.05)$. The MICs were $6.25,12.5,25$, and $50 \mathrm{mg} / \mathrm{mL}$ for $S$. aureus, F. nucleatum, E. coli, and C. perfringens, respectively $(P<0.05)$ (Table 2).

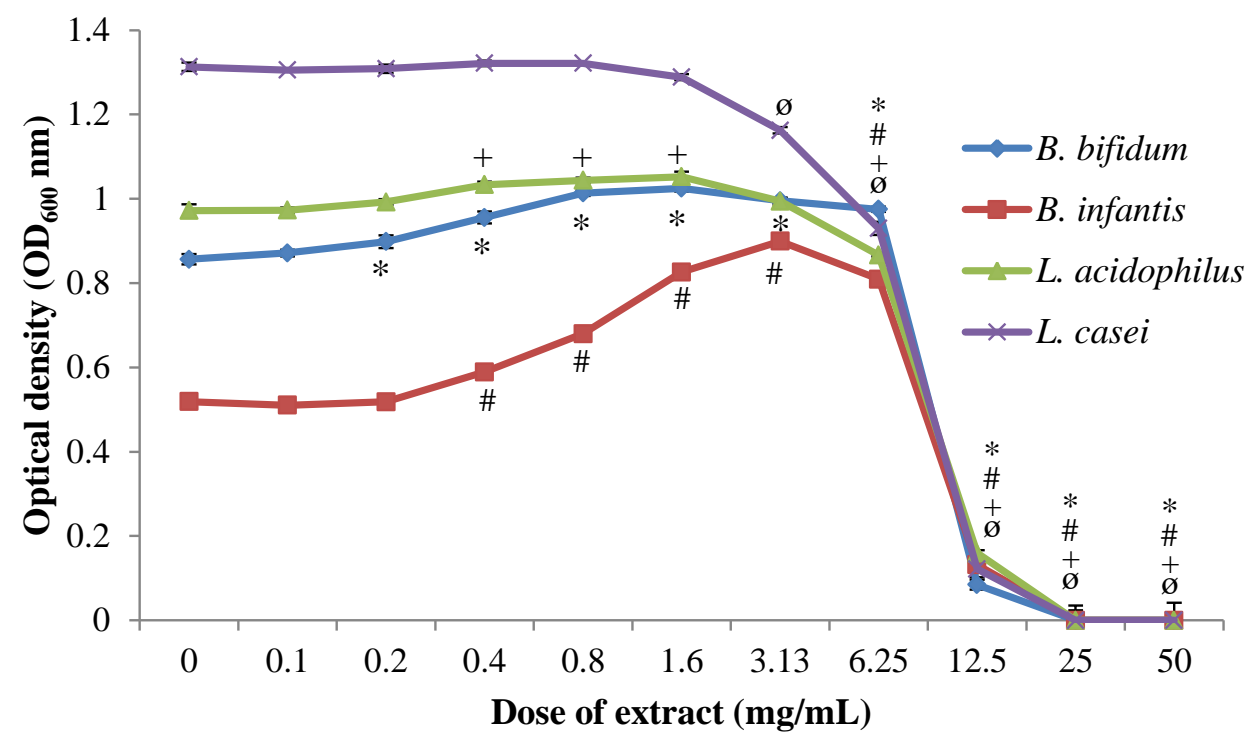

Figure 1. Effects of Turkish pine needle extract against commensal bacteria from the gut. The results represent the mean \pm standard error. ${ }^{*} P<0.05$, extract treated culture vs $B$. bifidum control; $\# P<0.05$, extract treated culture vs $B$. infantis control; ${ }^{+} P<0.05$, extract treated culture vs $L$. acidophilus control; and ${ }^{\circ} P<0.05$, extract treated culture vs $L$. casei control. Control level was $0 \mathrm{mg} / \mathrm{mL}$ of the extract. 


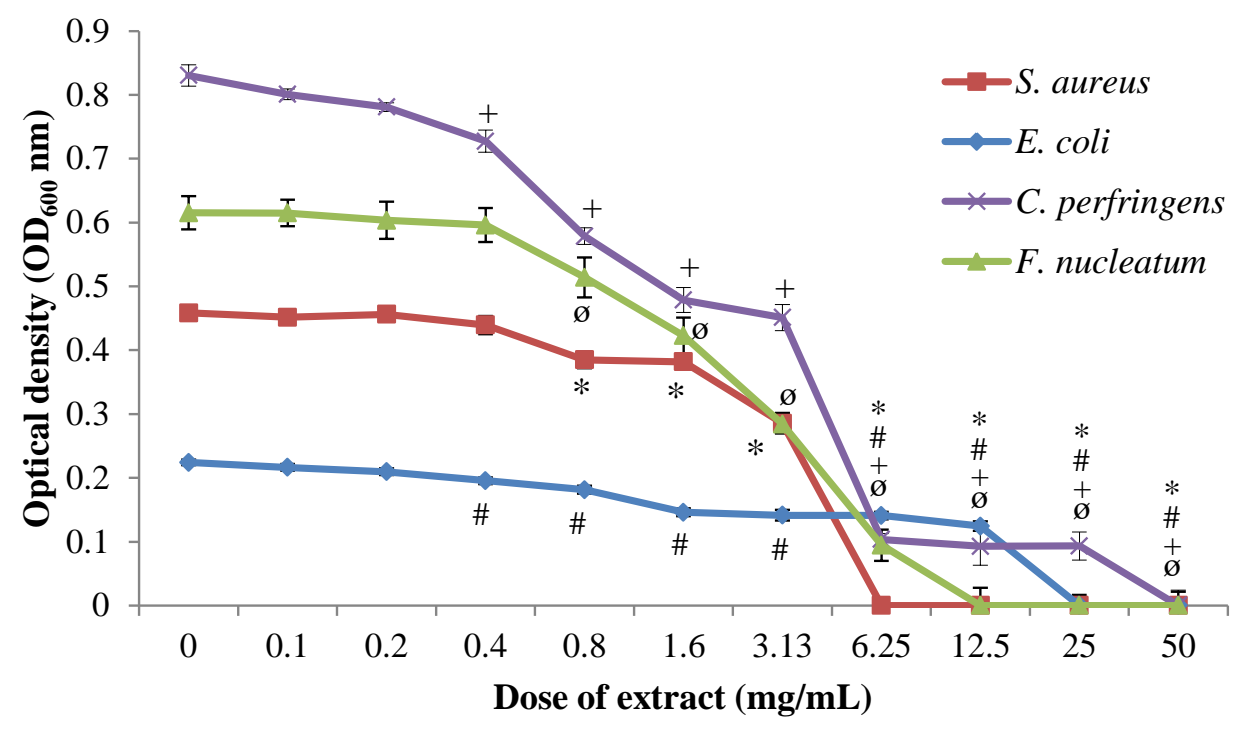

Figure 2. Effects of Turkish pine needle extract against pathogenic bacteria from the gut. The results represent the mean \pm standard error. ${ }^{*} P<0.05$, extract treated culture vs $S$. aureus control; $\# P<0.05$, extract treated culture vs E. coli control; ${ }^{+} P<0.05$, extract treated culture vs $C$. perfringens control; and ${ }^{\circ} P<0.05$, extract treated culture vs F. nucleatum control. Control level was $0 \mathrm{mg} / \mathrm{mL}$ of the extract.

Table 2. Minimum inhibitory concentration (MIC) values of Turkish pine needle extract on gut bacteria.

\begin{tabular}{lc}
\hline Bacteria & $\begin{array}{c}\text { MIC values } \\
(\mathbf{m g} / \mathbf{m L})\end{array}$ \\
\cline { 1 - 2 } Commensals & 25 \\
B. bifidum & 25 \\
B. infantis & 25 \\
L. acidophilus & 25 \\
L. casei & \\
\hline Pathogens & 6.25 \\
S. aureus & 25 \\
E. coli & 50 \\
C. perfringens & 12.5 \\
F. nucleatum & \\
\hline
\end{tabular}

\section{Discussion}

The presence of a diverse and balanced bacterial community in the gut is of great importance for host physiology. Disruption of commensal flora in the gut is one of the major complications encountered in the treatment of infections with antibiotics (Bäumler and Sperandio, 2016). Accordingly, to determine the safe dose range of therapeutic agents that protects commensal bacteria while suppressing pathogens has great importance in terms of gut health. Turkish pine needle extract at low concentrations stimulated the growth of B. bifidum, B. infantis, and $L$. acidophilus from commensals, more prominently for B. bifidum. However, this stimulatory effect turned into a potential inhibitory effect on Bifidobacterium species starting from $12.5 \mathrm{mg} / \mathrm{mL}$ and on L. acidophilus starting from $6.25 \mathrm{mg} / \mathrm{mL}$ concentrations. The extract completely inhibited all commensal species at $25 \mathrm{mg} / \mathrm{mL}$. Although there is no literature on the effects of Turkish pine needle extract on commensal gut bacteria, it was reported that low doses of several plant metabolites could stimulate bacterial growth in the gastrointestinal tract while high doses induced inhibition (Patra et al., 2012; Demirtas et al., 2019; Goker and Demirtas, 2020). Aldehydes, one of the plant secondary metabolites from the green leaf volatiles family, moderately promote the growth of L. acidophilus and B. bifidum at lower concentrations while had inhibitory effects at higher concentrations in a previous study (Goker and Demirtas, 2020). Trans-2-decenal, also an aldehyde from green leaf volatiles, stimulated the growth of Fibrobacter succinogenes, which is a fibrolytic bacterium from the rumen, at low doses 
(Demirtas et al., 2019). Similarly, saponins, another group of phytochemicals, encouraged in vitro bacterial growth and feed utilization in the rumen at low doses while they exhibited inhibition at high doses (Patra et al., 2012).

Escherichia coli and $S$. aureus are common foodborne pathogens that can cause severe gastro-intestinal illness (Ørskov and Ørskov, 1992; Rajkovic, 2014). The MIC value of Turkish pine needle extract for E. coli was $25 \mathrm{mg} / \mathrm{mL}$ in the present study. There is no literature on the effects of Turkish pine needle extract on pathogenic gut bacteria. However, Hmamouch et al. (2001) reported that the MIC value of the essential oil extracted from the needles of $P$. brutia grown in Morocco was higher than 10 $\mathrm{mg} / \mathrm{mL}$ for E. coli (ATCC 25922). This result is consistent with the result of this study. On the other hand, it was observed that $S$. aureus was the most sensitive bacterium to Turkish pine needle extract in the present study. The extract exhibited inhibitory activity against $S$. aureus at $6.25 \mathrm{mg} / \mathrm{mL}$ dose. Extract from pine needles of Cedrus deodara (Himalayan cedar), with the main antibacterial component of shikimic acid, inhibited the growth of $S$. aureus (ATCC 25923 ) at $0.78 \mathrm{mg} / \mathrm{mL}$ (Zeng et al., 2012). The difference in MIC values is probably due to the difference in bacterial strains and also due to active ingredients in needles of the pine trees from the different origins. The dominant flavonoids found in the needles of $P$. brutia were reported as quercetin (41\%), kaempferol (29\%), and isorhamnetin (\%23) (Kaundun et al., 1997) while the main essential oil component was reported as $\beta$-pinene (Yener et al., 2014). In this study, one or more of these active ingredients, that were likely to be contained in the extract, might be responsible for the antibacterial effects.

Fusobacterium nucleatum, which is obviously associated with colorectal cancer (Shang and Liu, 2018), was more sensitive to Turkish pine needle extract than $C$. perfringens in the present study. Extract from the barks of $P$. brutia also had an inhibitory potential on this bacterium from 150 $\mu \mathrm{g} / \mathrm{mL}$ concentration in a previous study (Demirtas, 2020). On the other hand, C. perfringens, which is generally linked to gastrointestinal symptoms such as vomiting and diarrhea (Keeratirathawat et al., 2013), was the most resistant species to the used extract in this study. Turkish pine needle extract inhibited the growth of this bacterium at $50 \mathrm{mg} / \mathrm{mL}$. Keeratirathawat et al. (2013) also reported that oils from the needles of four different Pinus species (Pinus radiata, P. pinaster, P. sylvestris, and $P$. nigra) did not exhibit any antibacterial activity against $C$. perfringens.

It was concluded that using the Turkish pine needle extract in a dose range of 0.2-6.25 $\mathrm{mg} / \mathrm{mL}$, where it protected most of the commensal bacteria and was toxic against some of the pathogens, might produce desirable impacts in the gut. Further in vitro and in vivo studies required to clarify its beneficial effects on the gut health.

\section{References}

Ahn, Y.J., Lee, C.O., Kweon, J.H., Ahn, J.W., Park, J.H., 1998. Growth-inhibitory effects of Galla Rhois-derived tannins on intestinal bacteria. Journal of Applied Microbiology 84(3), 439-443.

Balaban Ucar, M., Ucar, G., Pizzi, A., Gonultas, O., 2013. Characterization of Pinus brutia bark tannin by MALDI-TOF MS and 13C NMR. Industrial Crops and Products 49, 697-704.

Bäumler, A.J., Sperandio, V., 2016. Interactions between the microbiota and pathogenic bacteria in the gut. Nature 535(7610), 85-93.

Canny G.O., McCormick B.A., 2008. Bacteria in the intestine, helpful residents or enemies from within? Infection and Immunity 76, 3360-3373.

CLSI (Clinical and Laboratory Standards Institute), 2016. M100-S26, Performance standards for antimicrobial susceptibility testing. 26th Informational Supplement, Wayne, PA, CLSI.

Das, A., Datta, S., Mukherjee, S., Bose, S., Ghosh, S., Dhar, P., 2015. Evaluation of antioxidative, antibacterial and probiotic growth stimulatory activities of Sesamum indicum honey containing phenolic compounds and lignans. LWT - Food Science and Technology 61, 244-250.

Demirtaş, A., 2020. Influence of Pinus brutia bark extract containing phenolic compounds on some commensal and pathogenic bacteria from the intestinal 
microflora. Veterinary Journal of Mehmet Akif Ersoy University 5(2), 34-39.

Demirtas, A., Ozturk, H., Sudagidan, M., Keyvan, E., Yavuz, O., Yildı-Gulay, Y., Musa, S.A.A., 2019. Effects of commercial aldehydes from green leaf volatiles (green odour) on rumen microbial population and fermentation profile in an artificial rumen (Rusitec). Anaerobe 55, 83-92.

Goker, G., Demirtas, A., 2020. Preliminary study on stimulatory and inhibitory effects of aldehydes from the green leaf volatiles family on beneficial and pathogenic bacteria from the intestine. Medycyna Weterynaryjna 76(3), 170-175.

Hmamouchi, M., Hamamouchi, J., Zouhdi, M., Bessiere, J.M., 2001. Chemical and antimicrobial properties of essential oils of five Moroccan Pinaceae. Journal of Essential Oil Research 13(4), 298-302.

Hobson, P.N., 1969. Rumen Bacteria. In: Methods in Microbiology. London and New York, Academic Press, pp. 133-149.

Hwang, Y.H., Lee, H.S., 2002. Antibacterial activity of Pinus densiflora leaf-derived components toward human intestinal bacteria. Journal of Microbiology and Biotechnology 12(4), 610-616.

Kaundun, S.S., Fady, B., Lebreton, P., 1997. Genetic differences between Pinus halepensis, Pinus brutia and Pinus eldarica based on needle flavonoids. Biochemical Systematics and Ecology 25(6), 553-562.

Keeratirathawat, S., Nair, J., Levitan, J., 2013. The antibacterial efficacy of pine oils on pathogens commonly found in biosolids applied to pine plantations. International Journal of Environment and Waste Management 12(2), 146-153.
Ko, H.H, Lareu, R.R., Dix, B.R., Hughes, J.D., 2018. In vitro antibacterial effects of statins against bacterial pathogens causing skin infections. European Journal of Clinical Microbiology 37, 1125-1135.

Ørskov, F, Ørskov, I., 1992. Escherichia coli serotyping and disease in man and animals. Canadian Journal of Microbiology 38(7), 699-704.

Patra, A.K., Stiverson, J., Yu, Z., 2012. Effects of quillaja and yucca saponins on communities and select populations of rumen bacteria and archaea, and fermentation in vitro. Journal of Applied Microbiology 113, 1329-1340.

Rajkovic, A., 2014. Microbial toxins and low level of foodborne exposure. Trends in Food Science \& Technology 38(2), 149-57.

Shang, F.M., Liu, H.L., 2018. Fusobacterium nucleatum and colorectal cancer: A review. World Journal of Gastrointestinal Oncology 10(3), 71-81.

Üner, B., Karaman, İ., Tanrıverdi, H., Özdemir, D., 2011. Determination of lignin and extractive content of Turkish Pine (Pinus brutia Ten.) trees using near infrared spectroscopy and multivariate calibration. Wood Science and Technology 45(1), 121 134.

Yener, H.O., Saygideger, S.D., Sarikurkcu, C. Yumrutas, O., 2014. Evaluation of antioxidant activities of essential oils and methanol extracts of Pinus species. Journal of Essential Oil Bearing Plants 17(2), 295-302.

Zeng, W.C., He, Q., Sun, Q., Zhong, K., Gao, H., 2012. Antibacterial activity of water-soluble extract from pine needles of Cedrus deodara. International Journal of Food Microbiology 153(1-2), 78-84. 